\title{
ПОЛІТИЧНІ НАСТРОЇ І КОНСТРУЮВАННЯ ОБРАЗУ ВЛАДИ УНР ТА ЗУНР У СПРИЙНЯТТІ УКРАЇНСЬКИХ ОФІЦЕРІВ (1918-1920 pp.)
}

У статті висвітлені особливості політичних настроїв офіцерів армій УНР та УГА в період урядування Директорії та влади ЗУНР в 1918 1920 рр. Особлива увага присвячена конструюванню образу влади УНР і ЗУНР у сприйнятті українських офріцерів на тлі революційних, воєннополітичних подій на українських землях протягом означеного періоду. Подано характеристики взаємин, елементи конфронтації між урядами, політичними керівниками УНР та ЗУНР з одного боку, і наддніпрянськими та наддністрянськими офіцерами з іншого.

Ключові слова: офіцери, влада, революція, Україна, УНР, ЗУНР, Симон Петлюра, Свген Петрушевич.

Постановка проблеми та ї̈ актуальність. У результаті падіння Російської та Австро-Угорської імперій офіцери стали одним з репрезентантів українського національного руху зі своїм світоглядом та суспільно-політичними настроями. А тому вони не могли стояти осторонь політичних процесів на українських землях у революційний час. Опираючись на індивідуальний досвід українських офіцерів, зважаючи на їх пріоритети, образ української влади - урядів, i окремих політичних лідерів, містив як позитивні, так і негативні компоненти. На конструювання образу впливали вибір політичного шляху владою УНР і ЗУНР, їхні політичні коливання, подекуди нехтування вимогами та вподобаннями офріцерства.

$B$ українській історіографрї пропонована тема не була висвітлена дослідниками. Тому для розкриття проблеми були залучені джерела, головно спогади наддніпрянських i наддністрянських офіцерів та архівні матеріали 3 Національної Бібліотеки у Варшаві, ЦДАГО України,

Тютенко Роман Володимирович, аспірант кафедри історичного краєзнавства, Львівський національний університет імені Івана Франка, м. Львів.

() Тютенко Р. В., 2017 
Львівської національної наукової бібліотеки імені Василя Стефаника та Гуверівського інституту.

Метою поданого дослідження було проаналізувати спектр політичних настроїв офіцерів армій УНР та УГА та простежити конструювання образу української влади у сприйнятті офіцерського середовища в добу Директорії УНР та ЗУНР у період Української революції 1917-1921 рр.

Виклад основного матеріалу дослідження. Лютнева революція 1917 р. і падіння Російської імперії активізували суспільно-політичне життя на українських землях, активною групою в якому були українські військові. Офіцери ще на початках творення державності підтримали Центральну Раду в її починаннях як захисницю українських інтересів, бо сподівалися творити міцну державу та армію. Політичні погляди офріцерів та Центральної Ради збігалися. Вони бачили майбутній державний устрій колишньої Російської імперії як федеративну демократичну республіку, в якій Україна мала бути автономною одиницею. Але нерішучість політиків Центральної Ради перед війною з більшовицькою Росією офіцерів тільки дратувала.

Варто відзначити, що наприкінці 1918 р. невдоволеність політикою гетьмана П. Скоропадського, з утворенням ЗУНР після Листопадового Чину, схилила молодших старшин навіть на розмови про перехід до лав Галицької Армії [19, c. 257-258]. Авторитет Павла Скоропадського упав серед військових і через арешт Симона Петлюри, який користувався популярністю в українському суспільстві, і через гетьманський наказ про звільнення всіх молодих офіцерів, які не мали відповідної військової освіти з армії до резерву [22, с. 45]. В той час, полковник Петро Болбочан, генерали Всеволод Петрів і Олександр Натіїв, зустрічаючись з Вільгельмом Габсбургом (Василем Вишиваним), пропонували йому об'еднати групи військ для організації перевороту і очолити керівництво українським урядом [23, арк. 46].

А особливо надто негативного образу гетьманській владі надав маніфест Павла Скоропадського про федерацію України з майбутньою небільшовицькою Росією. Цей акт 
спричинив відмову від присяги гетьманові. Наприклад, офіцери Сірожупанної дивізї підтримали свого командира, який сказав: «Від присяги на вірність і послух гетьманові Скоропадському вважаю себе звільненим, бо я присягав Гетьманові як суверенові самостійної Української Держави, якій він сам дав присягу бути їй вірним. Раз Скоропадський цю присягу порушив, тим звільнив нас від присяги йому...» [19, с. 261]. Серед Січових Стрільців висловлювались думки про призначення полковника Василя Вишиваного новим гетьманом України [4, с. 81].

На хвилі антигетьманського повстання і початку нової війни з більшовиками прихильність до Симона Петлюри зростала. Тому військовики в той час казали: «Наша головна влада - Директорія» [1, с. 254]. Наприклад, офіцери Сірожупанної дивізії не торкаючись сощіально-політичної програми політиків Директорії УНР, визнали їі, знаючи тільки, що вона заснована на грунті самостійності України, тоді як Павло Скоропадський цю самостійність зрадив [18, с. 86]. Як вважав генерал Микола Капустянський, що зі свого боку, члени Директорії УНР, зокрема Андрій Макаренко, до військових «ставилися добре і рахувалися з ними» [9, с. 131]. Однак, Володимир Винниченко «не вірив у це, що в них можливо правдива революційна стихія» [14, с. 67]. Політика ж Володимира Винниченка мала підтримку далеко не у всіх офріцерів. Наприклад, про нього казали, що «письменник і драматург він прекрасний, а от політик з нього, як виявилось, нікчемний» [2, с. 148]. Водночас у середовищі офіцерів ставлення і до Симона Петлюри було неоднозначне. 3 одного боку, С. Петлюра, попри невійськову освіту, виступав як «патріот», «добрий промовець», «людина здібна» [1, с. 204]. Але з іншого боку, була скептичність щодо його фаховості, компетентності. Так, Василь Кучабський писав, що той очолив армію механічно, не мав жодної уяви про сутність регулярної армії як єдиного організму і керувався у військових питаннях не знанням, а силою. Через це він не надто довіряв кадровим вищим офріцерам колишньої російської армїі [28, s.120]. 
Окрім того, ставлення офіцерів до отаманів і їх повстанських загонів здебільшого негативно, оскільки ті дотримувались гасел «Все дозволено», «Грабуй награбоване!». Були і такі отамани, що ніби виступали з народними гаслами, але не визнавали жодної влади. Сотник Никифор Авраменко згадував: «Була це стихійна неорганізована сила, пильнувала єдине: свого села, волості а навіть повіту...Далеко ці «отамани» не дивились» [1, с. 258]. Зокрема, виступ отамана Володимира Оскілка проти Симона Петлюри у квітні 1919 р. офіцери не підтримали. Як згадував підполковник армії УНР Василь Прохода, що в той час урядові перевороти не мали значення, оскільки боротьбу за незалежність провадили кращі військові частини без огляду на урядовий політичний курс. I в цій боротьбі об’єднавчим було ім'я Симона Петлюри: «Всі були петлюрівцями, не знаючи й не бачивши особи самого Петлюри, як то було й зі мною особисто. Стати оскілковцями вони вже не могли» [17, с. 44].

Хоча, існувало чимало випадків переходу офіцерів від армії УНР до повстанських отаманів, зокрема до отамана Зеленого. Наприклад, у доповіді члена організащії «Чінізеллі» повідомлялося про настрої військовиків отамана Зеленого. Вони були налаштовані негативно і до Симона Петлюри, i до радянського уряду Християна Раковського: «Прежде всего мы стамостійники. Я - самостійникъ. Атаманъ Зеленый - какъ я. Мы считаемъ, что правительство Раковского великорусское и узурпаторское. Великороссія нась грабить, вьвозить оть насъ хлћбъ. Посадили намъ жидовъ - комиссаровъ...Долженъ быть кордонъ между Великороссіей и Украиной» [27, р. 119].

У той же час, наприкінці 1918 р. у ході революційних подій на території Австро-Угорщини, напередодні Листопадового Чину, між галицькими політиками і офіцерами виникла конфронтація. Деякі політики Української Національної Ради, такі як Кость Левицький і Лонгин Цегельський, не схвалювали акт повстання, вони були проавстрійськи налаштовані і вважали, що потрібно чекати кур'єра 3 Відня для подальших переговорів. Політики не поспішали 
довіряти військовим і були певні, що військова акція зашкодить переговорам з Віднем. В цьому моменті, щодо щих австрофільських настроїв українських політиків напередодні листопадових подій влучно висловився отаман М. Тарнавський, говорячи, що «іілька українських генералів у австрійській армії могло більше зробити для нашої справи у Відні, як ціла тогочасна парляментарна репрезентація. А що вже казати про 1918-1920 роки...»[20, с. 9]. Однак, група офіцерів на чолі із Дмитром Вітовським заявили, що відкладати не можна, бо Львів можуть взяти поляки. Рішучість Д. Вітовського вплинула на членів УНРади [8].

Усе ж, українські офџцери підтримали український уряд, оскільки це вже була своя влада, а не австрійська. Наприклад, Осип Колодницький по приїзді з Угорщини на Станиславівщину згадував: «..побачив я свою українську владу, про що колись мріяти навіть не було можна» [11, с. 28].

3 боку військовиків УГА траплялося несхвалення антигетьманського виступу через можливе поглиблення і так досить складної воєнної ситуації. Вони хоч і розуміли, що «останній, перед самим упадком, акт Гетьмана важко похвалити», однак вважали, що «тепер, коли маємо такі і стільки фрронтів, це повстання не віщуе добра нашої Держави» [16, с. 20].

Під час польсько - української війни 1918 - 1919 рр. становище офіцерів ставало чим раз складнішим. Воєнні поразки, особливо втрата Львова, позначилися на політичних настроях офіцерів. Так, хорунжий УГА Микола Опока у своїх листах до Ростислава Заклинського [21] писав: «о до політики то тут такий настрій, що всьо страшно невдоволене теперішним відношенням, нарікають на непорядки, хабарництво... »[13, арк. 8]. Невдоволеність політикою підсилювало прагнення встановити одноосібну диктатуру: «Майже всі старшини домагаються диктатури і може здаєся, що це було би ще одним виходом з дурної ситуації. Диктатор проголосив би Святу Війну з Польщею, всякі непорядки і саботаж каралися би смертю, а тоді здаєся польська армія розлетілася би...» [13, арк. 8]. В умовах поразок у 
війні з поляками, за які офіцери звинувачували Державний секретаріат ЗУНР, диктатура додавала якоїсь більшої впевненості у складний час. Зокрема, поручник Петро Кривоносюк у споминах відзначив: «До підняття настрою та збільшеня одушевленя серед війська причинив ся також фракт, що нездарний Секретаріят утік до Румунії, а всю власть обняв диктатор Др. Петрушевич» [24, s. 267].

Після переходу УГА р. Збруч з'явилися певні оптимістичні сподівання на нове військо. Але військовики УГА не погоджували фінансові асигнування уряду УНР, які йшли більше отаманам, аніж на нову армію. Так, сотник УСС М. Девоссер писав про це: «Якби влада УНР, замість витрачати гроші на підмогу різним «отаманам» на їхні, мовляв, тисячні (неконтрольовані!) підпільні «геройські армії»... була асигнувала ті суми на цю нову, свіжу, не змучену армію..., - то до ранньої весни можна вже було б розпочати нову, успішну воєнну кампанію» [5, с. 62].

У наслідок Київської катастрофи в серпні 1919 р. відносини між армією і владами ЗОУНР і УНР загострилися. Зокрема, 28 жовтня 1919 р. на спільній нараді галицьких і наддніпрянських керівників разом з Головним Отаманом C. Петлюрою і диктатором Є. Петрушевичем представник від УГА після всіх виступів заявив: «Мусить наступити негайна зміна кабінету; ввести до нового кабінету людей, яким вірить Галицька Армія; ввести військових, викинути Мартоса, Вітика і Безпалка, скликати предпарлямент» [6, с. 269]. На це С. Петлюра сказав, що «Мене дивує, що регулярна армія ставить політичні домагання...» [6, с. 269], а С. Петрушевич заявив: «Де ж ви бачили, щоб якась дисциплінована, европейська армія ставила своєму урядові такі вимоги? Всі болі устануть і ми вийдемо побідниками» [6, с. 269]. Після загострення воєнного становища отаман О. Сальський доповів, що «військо зробило все - тепер діло правительства шукати виходу»[6, с. 271].

Новий уряд УНР Бориса Мартоса до української армї ставився за означенням М. Капустянського «невиразно». Як останній відзначив, за думкою деяких політиків армія 
була «чинником другого порядку». Сам же уряд не зміг дієво організувати владу і не докладав необхідних зусиль, щоб своєчасно забезпечити армію обмундируванням, продовольством і ліками та дати їй грунт і засоби для продовження боротьби [9, с. 132]. Як писав I. Вислоцький, що серед офіцерів найгіршим було ставлення до Б. Мартоса через його висловлювання, що він хотів, щоб «Україна була така як він хоче - або жадна» [3, с. 5]. Взагалі уряд намагався очистити офріцерське середовище від різних шкідливих елементів, але це робилося однобічно, без якоїсь системи, що часто шкодило війську. Траплялася невдала ощінка офріцерів, навіть цькували їх у пресі, що відштовхнуло значний відсоток офщерів від уряду і сприяло розкладу армї $[9$, с. 40].

Та поряд з цим влада мусила віддати належне деяким отаманам, як наприклад Андрієві Гулому-Гуленку, Юркові Тютюннику, за їх партизанські здібності. Оцінюючи їхні якості, влада використовувала отаманів в своїх інтеpecax [15, с. 383].

Під час відступів УГА посилилися антиурядові настрої, невдоволення Диктатурою, а деякі військові навіть хотіли наказу Петлюри про арешт Є. Петрушевича. З УГА доносили телеграми, що «Галицькі козаки і старшини не розуміють, що сталося й через кого. Хто знає, а таких уже третина, активно виступає проти Н. К. і Диктатури. Невдоволення серед Галичан величезне... Вимагають єдиної команди на чолі з вами, пане отамане, білше нікому не вірять» [6, с. 312]. Але одночасно і Директорію вимагали, щоб «Петлюрі полишено тільки титул Головного Отамана, а усунено його від оперативних справ, бо він на тім не розуміється» $[15$, с. 383].

У середині 1919 р. в умовах воєнних поразок в середовищі офіцерів УГА і Армї УНР виникли різні політичні течї і настрої. Серед українських офіцерів були прихильники селянської України, диктатури пролетаріату та відновлення монархії. Щодо УГА зміна настроїв стала помітною після від”ззду з Галичини Є. Петрушевича. Зокрема, були 
офріцери правих поглядів, які симпатизували відновленню гетьманства в Україні з полковником В. Вишиваним. Інші ж офріцери в Начальній Команді Галицької Армії обговорювали заклик до України П. Скоропадського [3, с. 4]. Також сотник М. Курах згадував слова одного галищького офіцера австрофільських поглядів: «А я вам кажу і свою голову даю за те, що так довго не буде порядку і ми не виграємо нашої війни, як довго не будемо мати свого українського цісаря. Цісар як добрий господар на своєму господарстві, знає, що і як треба робити, щоби було добре. Того не знає жаден президент, тому я все буду проти республіки і президентів» [12, с. 39]. Деякі офіцери армї УНР трималися республіканських поглядів, вважали що доба царів і цісарів вже минула, прийшла черга республіканському ладу і навіть симпатизували В. Винниченкові: «Україна мусить бути республікою, а найкращим президентом був би Винниченко, бо він вийшов з українського села і найкраще розуміє всі потреби українського селянства» [12, с. 39].

Не бракувало і симпатиків більшовизму. Вони вважали, що «було б добре, якби ми мали свого Леніна або Троцького, бо їх програма найкраща: вони народові дають землю і волю, а вимагають лиш одного - щоби народ захищав здобутки революції» [12, с. 39]. У військових колах часто відбувались розмови на політичні теми, під час яких лунала критика С. Петлюри. Однак, подекуди старші офіцери, отамани не підтримували таких бесід, аргументуючи: «Так уже не годиться! Самі ми його вознесли, то нічого й носом крутить; мусимо й далі його триматись» [10, с. 115].

Поряд 3 цим низка українських офіцерів вважали, що «ми військо мусимо воювати і здобувати тую Україну» [12,с. 39]. Але в деяких військовиків взагалі була відсутня національна ідея: «Нам нет дела до політики, ми воєнні і наше дело воювать! Для кожного хороший той, - хто регулярно платить жалування... да здраствуєт Ленин, Троцкий, Винниченко і Франц Йосиф I-ий» [12,с. 39].

У 1920 р. під час міжнародних переговорів з країнами Антанти, з Польеею за Галичину в листуванні військовики 
частіше торкалися політичних тем: «Складається так сіткація, що всі майже держави стремляться... за всяку ціну мати мир на Сході Европи. Зовсім ніхто не захоче вести дальшої війни... »[26, s. 220]. Обговорювалися питання пошуку союзників в цих умовах: «Нам треба з цього вміти витягнути відповідні висновки зі сітуації. Треба нам шукать порозуміння і такого союзника, котрий був би відповідно до нашої ідеольогії і нашої праці найбільше підходячим. На кожний випадок ні Вранґель, ні Поляки таким союзником бути не можуть. На мою думку треба тому нам старатись в першу чергу налагоджувать звязок з цими галичанами, які залишились по другому боці кордону. По ідеольгії і по своїй праци вони нам найбільше підходять»[26, s. 221].

Політика Є. Петрушевича вже не мала підтримки в галицьких офщерів і за їхньою думкою навіть шкодила єдності України: «Ексклюзивна галицька політика Петрушевича... веде до що раз більшої прірви між Галичанами і Наддніпрянцями» [26, s. 221]. Особливо викликав обурення хід переговорів Симона Петлюри з Юзефом Пілсудським. Наприклад, говорилося, що особа «гол. от. Петлюри не $є$ нігде заграницею знана», що «його методи правління визивають заграницею підозріння, що найменше більшовикофрільства» [3, с. 4]. Після Варшавської угоди з Ю. Пілсудським C. Петлюра, на думку деяких галицьких офіцерів, «вже перестав бути репрезентантом всього ідейного Українства» [26, s. 221].

Уже в емігращії в Чехо-Словаччині військовик Ю. Лисак у своїх нотатках «На боівищї» 3 гіркотою писав: «Збруч холод - тифр - лазарети - бездарність вождів - смерть арміі в скитанні! Грізні слова, але правдиві» [25, s. 441].

Отже, українські офіцери в російській і австро-угорській арміях ще до революційних подій відчували зміни політичного ладу i, не зважаючи на суперечності у своєму середовищі, переважно прихильно їх сприйняли та підтримали свої уряди в процесі творення держав УНР і ЗУНР. Стосунки між українськими урядами та офріцерами спочатку проходили на сприятливому тлі, що, своєю чергою, 
формувало позитивний образ Петрушевича, Петлюри. Однак згодом помітне зростання критичного ставлення до них через недалекоглядні і непослідовні дії влади у вирішенні військових, політичних питань, у веденні війн з більшовиками, поляками, білогвардійцями. Ці урядові помилки призвели до появи різних політичних течій в офіцерському середовищі: австрофільства, більшовикофільства, прихильність до республіки, власної монархії. В результаті образ керівників УНР і ЗУНР набрав негативного характеру.

1. Авраменко Н. Спомини запорожця: Документальне видання / Н. Авраменко. - Київ: Темпора, 2007. C. 204.

2. Антоненко-Давидович Б. На шляхах і роздоріжжях: спогади, невідомі твори / Б. Антоненко-Давидович. Київ: «Смолоскип», 1999. - С. 172.

3. Вислоцький $I$. Політичні настрої і течії серед старшин У.Г.А. / І. Вислоцький // Літопис Червоної Калини. - 1934. - Ч. 11. - С. 5.

4. Вісті Комбатанта. - Ню Йорк, 1980. - № 1. - С. 81.

5. Девоссер М. На службі народу / М. Девоссер // Вісті Комбатанта. - Ню Йорк, 1973. - № 4. - С. 62.

6. Доценко О. Літопис Української революції. Матеріяли й документи до історії Української революції. Т. II. - Книга 4. - Київ-Львів, 1923. - С. 269.

7. Дубрівний П. Сірожупанники / П. Дубрівний // Вісті Комбатанта. - Ню Йорк, 1962. - № 3-4. - С. 41.

8. Заклинський $M$. Листопадовий зрив / М. Заклинський // Вісті Комбатанта. - Ню Йорк, 1969. - № 6. - С. 18; Заклинський $M$. Творці Листопадового чину / М. Заклинський // Вісті Комбатанта. - Ню Йорк, 1971. № 5. - С. 6; Крезуб $A$. Нарис історії українськопольської війни 1918-1919 / А. Крезуб. - Ню Йорк: «Око», 1966. - C. 32.

9. Капустянський $M$. «Похід Українських армій на Київ-Одесу в 1919 році». С. Маланюк «Уривки зі спогадів». Документи та матеріали: Документально-наукове видання / М. Капустянський / Передм. Я. Тинченко. К.: Темпора, 2004. -

10. Коваль P. Отаман Зелений: Історичний нарис / Р. Коваль. Бібліотека Історичного клубу «Холодний Яр». Київ: Історичний клуб «Холодний Яр»; Кам'янець-Подільський: ПП «Медобори-2006», 2011. - 464 с. 
11. Колодницький О. Моя служба в УГА / О. Колодницьккий // Вісті Комбатанта. - Ню Йорк, 1969. - № 2. - С. 28.

12. Курах M. Тост / М. Курах // Вісті Комбатанта. Ню Йорк, 1961. - № 3. - С. 39.

13. Львівська національна наукова бібліотека імені Василя Стефраника. Відділ рукописів. - Ф. 48. - Оп. 1. Спр. 147. - Арк. 8.

14. Назарук O. Рік на Великій Україні. Конспект споминів з Української революції. - Відень: Видання «Українського прапору», 1920. - С. 67.

15. Омелянович-Павленко $M$. Спогади командарма (1917 - 1920): Документально-художне видання / Упоряд.: М. Ковальчук / М. Омелянович-Павленко. - К.: Темпора, 2007. - C. 383.

16. Островерха М. Блиски і темряви. 1918 - 1919 1920 / М. Островерха. - Нью- Йорк 1966. - С. 20.

17. Прохода В. Бої сірожупанників на польському фронті / В. Прохода // Вісті Комбатанта. - Нью-Йорк, 1969. - № 6. - C. 44.

18. Прохода В. Записки до історії Сірих (Сірожупанників) / В. Прохода // За державність. Матеріяли до історії війська українського. - Каліш, 1935. - Збірник 1. C. 81.

19. Прохода В. Записки непокірливого / В. Прохода. Торонто. - 1969. - Кн. 1. - С. 261.

20. Тарнавський M. Спогади / М. Тарнавський. Львів, 1992. - С. 67.

21. Тютенко Р. Листи хорунжого УСС Миколи Опоки до Ростислава Заклинського як джерело до вивчення повсякдення офіцерів Галицької Армії / Роман Тютенко / Емінак: науковий щоквартальник. - 2016. - № 3 (15) (липень-вересень). - Т. 1. - С. 112-116.

22. Удовиченко O. Україна у війні за державність. Історія організації і бойових дій Українських Збройних Сил 1917-1921. / О. Удовиченко. - Київ: Видавництво «Україна», 1995. - С. 41.

23. Центральний державний архів громадських об’єднань України (далі - ЦДАГО України). - Ф. 263. Оп. 1. - Спр. 66498. - Т. 1. - Арк. 46.

24. Biblioteka Narodowa w Warszawie. - Zakład Zbiorów Mikrofilmowych. - MF nr. 69010.

25. Biblioteka Narodowa w Warszawie. - Zakład Zbiorów Mikrofilmowych . - MF nr. 87285. 
26. Biblioteka Narodowa w Warszawie. - Zakład Zbiorów Mikrofilmowych . - MF nr. 87287.

27. Hoover Institution Archives. - Vrangel Collection 1916-1929. - Box 38. - Folder 1. - P. 119.

28. Kutschabsky W. Die Westukraine im Kampfe mit Polen und dem Bolschewismus in den J ahren 19181923 / W. Kutschabsky. - Berlin: J unker u. Dünnhaupt, 1934. - S. 120.

Надійшла до редколегії 11.08.2017 р.

Рецензент: Якимович Б.З., доктор історичних наук, професор, провідний науковий співробітник Наукового центру Національної академії сухопутних військ імені гетьмана Петра Сагайдачного, м. Львів.

\section{Tiutenko Roman}

\section{THE POLITICAL MOODS AND THE CONSTRUCTION OF IMAGE OF THE UKRAINIAN PEOPLE'S REPUBLIC'S AND THE WEST UKRAINIAN PEOPLE'S REPUBLIC'S AUTHORITIES IN THE PERCEPTION OF THE UKRAINIAN OFFICERS (1918-1920)}

In the article a features of the political moods of the and Ukrainian officers during the rule of Directory of Ukrainian People's Republic and government of the West Ukrainian People's Republic in 1918-1920 have been highlighted. There are a comparison of political views of the Ukrainian Galician Army's and Ukrainian People's Republic's officers. A special attention is paid to the design of the image of the Ukrainian People's Republic and the West Ukrainian People's Republic authorities in the perception of Ukrainian officers against the backdrop of the revolutionary, military and political events in the Ukrainian lands for a certain period. The characteristics of relationships, confrontation elements between governments, individual political leaders of the UPR, WUPR and Ukrainian officers have been selected.

Keywords: officers, authority, revolution, the Ukrainian People's Republic, the West Ukrainian People's Republic, Symon Petliura, Yevgen Petrushevych. 